\title{
INSIDER TRADING AND CONTRACTING: A CRITICAL RESPONSE TO THE "CHICAGO SCHOOL"
}

\author{
JAMES D. CoX*
}

American jurisprudence abhors insider trading ${ }^{1}$ with a fervor reserved for those who scoff at motherhood, apple pie, and baseball. The commonly stated reasons for this reaction to insider trading are many and unpersuasive. The case law barely suggests why insider trading is harmful. The Supreme Court has condemned insider trading under the federal securities laws when the trading violates a fiduciary's obligations. ${ }^{2}$ The Court did so, however, without revealing how such trading harms the corporation, threatens investors, or erodes the functioning of securities markets. Commentators have attempted to coinplete the opaque mosaic left by the Court's reasoning by advancing two theories. First, they argue that insider trading is unfair. ${ }^{3}$ Second, they offer highly refined

* Professor of Law, Duke University School of Law. The author is grateful for the support of the E.T. Bost Research Professorship during the preparation of this article.

1. This article uses the term "insiders" to refer to those who hold nanagerial positionscorporate officers, directors, and middle managers-within the business organization. Recent enforcenent practices have given insider trading a broader context by focusing on various types of professionals, from lawyers to investment bankers to printers. This article does not focus on these professional groups because with respect to such groups it is easy to justify the regulation of insider trading. These professionals usually trade using information that the client has generally taken great steps to kecp secret. An early release of this information through the professional's trading unquestionably threatens the chient's interest. See, eg., Power, Litton Sues Levine, Shearson Lehman Over Itek Trading, Wall St. J., Aug. 20, 1986, at 2, col. 3. The best evidence of this thrcat is the fact that the professional is swiftly disnissed when his eniployer discovers that he has abused the client's trust by trading on the client's information. On the other hand, there is no evidence that einployers dismiss officers, directors, or even middle managers for insider trading. The free-market proponents argue that insider trading gives officers, directors, and managers an incentive to create events so that they can trade. The presence of these factors makes inquiry into the trading by officers, directors, and inanagers a more puzzling problem than is the case with respect to market professionals.

2. See Chiarella v. United States, 445 U.S. 222 (1980).

3. The inost elusive complaint lodged against insider trading is that it is "unfair." This complaint has two distinct aspects. First, the insider is seen as having an unerodible advantage over others who cannot obtain the same information. Second, the information was produced not for the benefit of the inside trader, but rather as a result of the employer's quest for gain. See Brudney, Insiders, Outsiders, and Informational Advantages Under the Federal Securities Laws, 93 HARV. L. REV. 322, 356-57 (1979). The second point is an indispensable qualification of the first in characterizing trading as unfair, because the experience, intelligence, resources, or position of some investors will always give them superior insight into prospective market developments. For example, a brokerage house first inakes its recommendations to its most important clients. Additionally, no one believes that it is "unfair" for an investor to purchase a security without disclosing his belief that the 
arguments explainimg how insider trading impacts the corporation's operation, ${ }^{4}$ investor behavior, 5 and the allocational efficiency of capital markets. ${ }^{6}$ The indeterminacy of these approaches is examimed closely below.

Part I of this article criticizes the Supreme Court's contemporary justifications for regulatimg insider tradimg. ${ }^{7}$ It develops the view that the

stock is a "bargain." Disclosure of such information would be dysfunctional because such disadvantages are inherent and necessary components of an exchange economy. See Hethrington, Insider Trading and the Logic of the Law, 1967 WIS. L. REv. 720, 725-30. Allowing the producer of information to prohibit another's use of that information is socially desirable in certain circumstances. See Barry, The Economics of Outside Information and Rule 10b-5, 129 U. PA. L. REV. 1307, 132328 (1981).

The concept of "unfairness" represents nothing more than a highly stylized line separating lawful and unlawful conduct. There are substantial "fairness" justifications for identifying investors who use an informational advantage for trading purposes. These include protecting the economic benefits that accompany both the production of the imformation and its private use by its producer. See Fleischer, Mundheim \& Murphy, An Initial Inquiry into the Responsibility to Disclose Market Information, 121 U. PA. L. REv. 798, 808-09 (1973). The logic of the opposite side of this fairness argument, however, is not intuitively obvious. The need to encourage economically desirable conduct may justify one party's use of nonpublic information, but the same need does not necessarily proscribe a second person from using the same information, so long as the second person's use does not impair the first person's use. In fact, commentators who favor the legalization of insider trading have turned the fairness argument around by arguing that permitting insider trading provides incentives to undertake economically worthwhile activities. See Carlton \& Fischel, The Regulation of Insider Trading, 35 STAN. L. REV. 857, 866-72 (1983). These free-market proponents have argued that information differs from most commodities in that one person's use of the information does not necessarily prevent another person from gaining equal or greater advantages from the sanie information. Thus, "unfairness" by itself is an insufficient basis to condemn insider trading. Professor Brudney, however, coupled "unfairness" argunients with concerns over whether insider trading harms market efficiency, impairs market integrity, induces manipulative practices, or increases the corporation's cost of capital. Brudney, supra, at 334-35, 356.

4. Relying on organizational behavior literature, Professor Haft has suggested that a laissez faire approach toward insider trading will promote information delays, manipulation of corporate releases, and intrafirm competition that is harmful to the corporation. See Haft, The Effect of Insider Trading Rules on the Internal Efficiency of the Large Corporation, $80 \mathrm{MICH}$. L. REV. 1051, 1051-64 (1982). Haft fails to consider an equally plausible middle ground: that market constraints prevent insiders from trading to an extent that their trading significantly harms the corporation. Professors Jensen and Meckling suggest that the market for managerial talent and corporate control operate as such preventative market constraints. See Jensen \& Meckling, Theory of the Firm: Managerial Behavior, Agency Costs and Ownership Structure, 3 J. FIN. EcoN. 305, 328-29 (1976). These market constraints on excessive insider trading are not, however, absolute under the Jensen and Meckling model. Professors Jensen and Meckling argue that a certain anıount of managerial misbehavior is optinual. Id. at 345-51.

5. See, e.g., Wang, Trading on Material Nonpublic Information on Impersonal Stock Markets: Who is Harmed, and Who Can Sue Whom Under SEC Rule 10b-5?, 54 S. CAL. L. Rev. 1217, $1235-$ 40 (1981) (arguing that insider trading either induces the unwitting investor to trade or preempts a price otherwise available to an outsider).

6. See, e.g., Seligman, The Reformation of Federal Securities Law Concerning Nonpublic Information, 73 GEO. L.J. 1083, 1115-20 (1985) (investors prefer markets where managers have no hidden incentive to delay release of information and are otherwise compelled to disclose all material information prior to their private use of that information).

7. See infra notes 11-31 and accompanying text. 
limitations that Chiarella v. United States and Dirks v. SEC impose on the disclose-or-abstain rule are completely artificial. Part II challenges the prevalent view that insider trading affects the market's allocational efficiency. ${ }^{8}$ Accepting the assumption that insider trading leads to the manipulation of corporate disclosures, this article uses the capital market theory to demonstrate that insider trading harms neither the individual investor nor the market's allocational efficiency. Part III critically analyzes and takes exception to the emerging arguments of those commentators who contend that the present form of insider trading regulation is unjustified and that the law should allow corporations to license their agents to engage in insider trading. ${ }^{9}$ Finally, in the wake of the exceptions taken to the Supreme Court and the coinmentators, Part IV provides a coherent justification for continuing the regulation of insider tradimg. ${ }^{10}$

\section{THE SUPREME COURT'S IMPACT ON INSIDER TRADING}

As originally formulated, the disclose-or-abstain rule prohibited trading by anyone on the basis of material nonpublic information. ${ }^{11}$ The Court formulated the rule believing that the integrity and efficiency of securities markets would be eroded if investors were not confident that all market participants enjoyed the same access to inside information when trading. ${ }^{12}$ For a while, this lofty mission guided the courts' holdings that the SEC, ${ }^{13}$ the injured investor, ${ }^{14}$ and the corporation in whose shares the defendant traded ${ }^{15}$ enjoy significant rights against violators of

8. See infra notes $32-48$ and accompanying text.

9. See infra notes $49-85$ and accompanying text.

10. See infra notes $86-93$ and accompanying text.

11. See SEC v. Texas Gulf Sulphur Co., 401 F.2d 833, 848 (2d Cir. 1968), cert. denied, 394 U.S. 976 (1969); Matter of Cady, Roberts \& Co., 40 S.E.C. 907,912 (1961).

12. See Texas Gulf Sulphur, 401 F.2d at $851-52$.

13. See id. The deterrence value of requiring the insider and his tippee to merely disgorge profits earned before public disclosure of the information is inherently weak. Current enforcement techniques include criminal actions by the Department of Justice as well as civil sanctions by the SEC. The government can impose a fine up to $\$ 100,000$, as well as a penalty up to three times the insider's profits. See infra note 56.

14. Private parties can recover only the insider's profits. See, e.g., Elkind v. Liggett \& Myers, Inc., 635 F.2d 156, 173 (2d Cir. 1980); cf. Fridrich v. Bradford, 542 F.2d 307, 322 \& n.33 (6th Cir. 1976) (expressing support for rule that limits recovery to amount of insider's profits), cert. denied, 429 U.S. 1053 (1977). The disgorgement remedy does not include the gains the individual trading investors would have reaped had the insider disclosed the information before trading. This remedy is consistent with the thesis of this article-that investors are not harmed by insider trading.

15. The corporation's right to recover its fiduciary's profits depends on the willingness of the particular jurisdiction to assume that trading harms the corporation. In Diamond v. Oreamuno, 24 N.Y.2d 494, 499, 248 N.E.2d 910, 912-13, 301 N.Y.S.2d 78, $81-82$ (1969), the New York Court of Appeals presumed that insider trading causes reputational injury to the corporation in all cases. In Freeman v. Decio, 584 F.2d 186, 191-96 (7th Cir. 1978), the United States Court of Appeals for the 
the disclose-or-abstain rule. The utopian dream of information parity among investors was short-lived, however. Two Supreme Court decisions have revolutionized the rule's application, rendering the rationale underlying insider-trading regulation a dark mystery.

In Chiarella v. United States, ${ }^{16}$ the Supreme Court lield that the only persons subject to the disclose-or-abstain rule are those witli a preexisting fiduciary relationship to the corporation in wliose shares they trade. Cliarella, a markup man employed by Pandick Press, broke the secret code that his employer devised to conceal the identity of its clients and their takeover targets. On five occasions Chiarella purcliased the target's shares before a takeover bid was announced. Justice Powell, writing for the majority, rejected the lower court's invocation of the socalled parity-of-information rule that "[a]nyone-corporate imsider or not-who regularly receives material nonpublic information may not use that information to trade in securities without imcurring an affirmative duty to disclose."17 The Court lield that Chiarella's fiduciary relationship was with Pandick Press and the bidder corporation. Chiarella did not liave a duty to disclose or abstain because lie did not have a fiduciary relationship with the target corporation in whose shares he traded. ${ }^{18}$

Later, in Dirks v. $S E C,{ }^{19}$ the Court underscored the importance of a preexisting fiduciary relationship when it lield that outsiders may freely trade on an insider's selective disclosure so long as the disclosure was not "improper."20 Secrist, a former officer of Equity Funding of America, informed Dirks, an imvestment analyst, that Equity Funding's assets were fraudulently overstated. In the course of his aggressive investigation, Dirks shared Secrist's revelations with five investment advisers. These advisers caused their clients to liquidate more tlian sixteen million dollars wortli of Equity Funding stock before the scandal was publicly disclosed. The Dirks Court easily could lrave held that since Secrist could not legally trade on the information, his tippees also could not trade. Instead, Dirks held that outsiders may freely trade on the insider's selective disclosure so long as that disclosure was not "improper."21 According to the Court, a disclosure is improper if the insider tips a relative or expects

Seventh Circuit considered whether the corporation could have lawfully used the information. And in Schein v. Chasen, 313 So. 2d 739, 746 (Fla. 1975), the Florida Supreme Court stated that it would permit recovery only upon proof of actual harm to the corporation.

16. 445 U.S. 222, 233-34 (1980).

17. United States v. Chiarella, 588 F.2d 1358, 1365 (2d Cir. 1978), rev'd, 445 U.S. 222 (1980).

18. Chiarella, 445 U.S. at 232-33.

19. 463 U.S. 646 (1983).

20. Id. at 659-60.

21. Id. 
to make a pecuniary gain from the selective disclosure. ${ }^{22}$

The threshold appeal of the Court's reasoning in Dirks lies in the fact that according analysts greater freedom furthers the efficient functioning of securities markets because it does not condemn the analyst to ferret out material nonpublic corporate information under a fear of violating the antifraud rule. This reasoning, however, has only a superficial appeal and fits the Dirks facts poorly. To be sure, the analyst and the corporate executive should be protected from draconian sanctions when the analyst, through persistence, has wrung an important selective disclosure from the executive and then made that disclosure generally available through a public medium. However, Dirks tipped his clients and attempted to give publicity to Equity Funding's fraudulent practices. In this respect, his gains were not all of the heart, but included earning commissions and establishing goodwill with the tipped clients.

Dirks's gains were no different than Merrill Lynch's gains garnered some years earher in Shapiro v. Merrill Lynch, Pierce, Fenner \& Smith. ${ }^{23}$ As lead underwriter for Douglas Aircraft, Merrill Lynch learned that Douglas's inventories were going to be written down because of production delays caused by the Vietnam War. Merrill Lynch tipped several of its clients, thereby triggermg a significant decline in Douglas Aircraft's stock before Douglas eventually announced the writedowns. There is little question that Merrill Lynch would have been beyond the Dirks protection. Under the Dirks view, Merrill Lynch would be an insider with disclose-or-abstain obligations similar to those of Secrist. ${ }^{24}$ On the other hand, if Merrill Lynch had not been Douglas's underwriter and a Douglas officer had gratuitously informed Merrill Lynch of the pending writedown, Merrill Lynch's position would have been identical to that of Raymond Dirks. In each case, however, the analyst's private gains are at the expense of unsuspecting buyers. Dirks does not exanine why duties under the disclose-or-abstain rule should depend upon the technical niceties of the analyst's position or the fact of a reward to an insider rather than upon some more useful insight into why eniployers prefer that trading and tipping by its insiders be circumscribed. Market efficiency is enhanced regardless of whether the analyst or other financial intermediary confers a benefit, financial or otherwise, upon the tipping insider. Moreover, it is quite reasonable to expect that a fiduciary's unauthorized premature disclosure could harm his employer's interests, regardless of whether he gains from that revelation. A further anomaly of Dirks is that state law, the source of all underlying fiduciary duties, does not re-

22. Id. at 663-64.

23. 495 F.2d 228 (3d Cir. 1974).

24. Dirks, 463 U.S. at 655 n. 14. 
quire a finding of personal gain as a prerequisite to establishing misconduct. ${ }^{25}$ Nevertheless, Chiarella and Dirks einphasized reward to the insider, not harm to the einployer.

Another development attributable to Chiarella is the so-called "misappropriation theory."26 Under this theory, an einployee who makes an unauthorized use of his employer's information by trading in another corporation's stock would appear to be violating Rule 10b-5's proscription of "any fraudulent scheme" by "any person" as well as reaping the kind of "undue trading advantage" that serves no "useful purpose" proscribed in the legislative history of the Exchange Act. Superficially, the misappropriation theory appears to be a natural analogue to Chiarella because it underscores the necessity for a fiduciary relationship to exist before the disclose-or-abstain rule apphes. Certainly an employee's misuse of his employer's property, whether that property be tangible or intangible, is a clear exainple of fiduciary misconduct. ${ }^{27}$ Moreover, the misappropriation theory is designed to protect the employer's property right to the information. ${ }^{28}$

25. See generally R. ClaRK, CORporate LAw 147-50, 155-56 (1986) (unfairness in "self-dealing" transactions arises from harm to either corporation or stockholders; such self-dealing harms corporation because it creates investor uncertainty over frequency and magnitude of self-dealing, thereby increasing the corporation's cost of capital); Frankel, Fiduciary Law, 71 CALIF. L. REv. 795, 821-32 (1983) (nature and extent of fiduciary's obligations arises from entrusting party's natural expectations of how fiduciary will discharge powers entrusted to him). There are of course instances in which corporate fiduciaries are required to disgorge their gains as a prophylactic measure, even though the corporation or its shareholders have suffered no tangible harm. See, e.g., Periman v. Feldman, 219 F.2d 173, 178 (2d Cir. 1955). Even in these cases, the remedy as well as the duty are driven by a concern for protecting the stockholders or the corporation froin potential harm.

26. Chiarella, 445 U.S. at $240-44$ (Burger, C.J., dissenting).

27. Some commentators argue that the presence or absence of a fiduciary relationship should be irrelevant under the misappropriation theory. They reason that the antifraud rule should be no less inclusive than the common law in removing informational advantages gained tortiously or illegally. See, e.g., Barry, supra note 3, at 1363. However, closer analysis reveals that the coinmon law imposes no duty to disclose to one party when information has been purloined from another. The common law only provides a remedy to the information's creator against the misappropriator of that information. See generally G. Bower \& A. TuRnER, THE LAW OF Actionable MisRepresenTATION 103-08 (1974). The disclosure obligation under the Supreme Court's misappropriation theory thus has no common law parallel. Even common law copyright and design cases provide a remedy for only the information's creator; they exclude those who deal with the misappropriator. Cf. Tabor v. Hoffman, 118 N.Y. 30, 34, 23 N.E. 12, 13 (1889) (inventor selling machine without pattern retains exclusive property right in machine's pattern). Moreover, a nonemployee's use of a creator's information results in the imposition of a constructive trust only if the nonemployee knew he acquired the information through another's breach of fiduciary duty. See Ohio Oil Co. v. Sharp, 135 F.2d 303, 306 (10th Cir. 1943).

28. Somc commentators have argued that in Chiarella and Dirks the Supreme Court intended to protect the corporation's "property interest" in the information. These commentators suggest that the Court's holdings should ultimately lead to recognizing the corporation's power to license insider trading. See e.g., Macey, From Fairness to Contract: The New Direction of the Rules Against Insider Trading, 13 HofsTrA L. REV. 9, 39-47 (1984). 
The misappropriation theory, even though a logical adjunct to the employer's expectations and the fiduciary obligations of its employees, resonates poorly with Rule $10 \mathrm{~b}-5$, the provision under which most parties prosecute insider trading cases. ${ }^{29}$ In other contexts, Rule $10 \mathrm{~b}-5$ is devoted to protecting investors and securities markets from deceptive practices. For example, in Santa Fe Industries v. Green ${ }^{30}$ the Supreme Court ruled that the antifraud rule did not apply when the coinplaint alleged no more than a breach of fiduciary duty or unfair dealings. The misappropriation theory, however, expands the antifraud rule to protect an employer's expectations that his employee will not use the employer's information for private gain. It is difficult to reconcile cases such as Santa Fe Industries with the inisappropriation cases because the misappropriation cases emphasize the "unfairness" to the employment relationship, ${ }^{31}$ regardless of the impact upon another's investment decision, and not deception and manipulation. More importantly, the Supreme Court's insider trading decisions have left in their wake only the empty concepts of "fiduciary," "improper disclosure," and "misappropriation." Neither these decisions nor subsequent lower court decisions consider the social benefits of regulating insider trading. The fact that such an aggressive level of regulation exists without a coherent, let alone articulated, philosophy of regulation is one of the most unsettling aspects of the federal securities laws.

29. In United States v. Newman, 664 F.2d 12 (2d Cir. 1981), the United States Court of Appeals for the Second Circuit attempted to bring the misappropriation theory within contemporary Rule 10b-5 jurisprudence by reasoning that injunctive relief is available under the antifraud rule even when the fraud did not give rise to a purchase or sale. As support, however, the court cited cascs that either involved market manipulation affecting the share's value or conduct compelling the plaintiff to sell his stock. See id. at 17 (citing Crane Co. v. Westinghouse Air Brake Co., 419 F.2d 787, 798 (2d Cir. 1969); and Mutual Shares Corp. v. Genesco, Inc., 384 F.2d 540, 546-47 (2d Cir. 1967)). The court also invoked Superintendent of Ins. v. Bankers Life \& Casualty Co., 404 U.S. 6 (1971), to reach fraudulent conduct affecting an employer. Bankers Life, however, upheld the application of Rule 10b-5 upon the plaintiff's allegation that the defendant had deceived the company's board of directors into selling their United States Treasury bonds. Id. at $8 \mathrm{n} .1$.

Investors who purchase from or sell to the misappropriating defendant lack standing to complain under the misappropriation theory because they are not the objects of the "fraud." See Moss v. Morgan Stanley, Inc., 719 F.2d 5, 16 (2d Cir. 1983), cert. denied, 465 U.S. 1025 (1984).

30. 430 U.S. $462,476-77$ (1977). The argument against the misappropriation theory is even stronger with respect to the antifraud provision of the Williams Act because the purpose of the Williams Act is to protect the shareholders of publicly traded corporations. See Schreiber v. Burlington N., Inc., $105 \mathrm{~S}$. Ct. 2458, 2463 (1985).

31. See, e.g., United States v. Carpenter, 1986 Fed. Sec. L. Rep. (CCH) 1 92,742, at 93,613 (2d Cir. 1986); SEC v. Materia, 745 F.2d 197, 201-02 (2d Cir. 1984), cert. denied, 105 S. Ct. 2112 (1985); United States v. Newman, 664 F.2d 12, 17 (2d Cir. 1981); SEC v. Musella, 578 F. Supp. 425, 437-38 (S.D.N.Y. 1984). 


\section{The Allocational Efficiency Argument}

The grafting of the misappropriation theory to the antifraud provision is one of the Court's most truthful admissions in applying Rule 10b5 to insider trading: the regulation of insider trading cannot be justified out of concern for protecting the unwary investor. Insider trading is at most a fortuity for the imvestor ${ }^{32}$ because the investor is no worse off when the imsider trades than when the imsider does not trade. ${ }^{33}$ The investor's decision to sell or purchase is unaffected by whether the insider is also secretly buying or selling shares im the open market. If the insider neither trades nor discloses his confidential material information, one can nevertheless expect the imvestor to pursue his trading plan. Sellers naturally are disadvantaged by the nondisclosure of good news, just as buyers are disadvantaged by the nondisclosure of bad news. These considerations, however, cast no hight on why the insider's decision to trade should prompt disclosure. Therefore, the focus turns toward a concern greater than the individual investor's mjury-namely, the operation of securities markets. Consequently, commentators have directed their attention to how insider trading affects the allocational efficiency of those markets. ${ }^{34}$

Commentators have spent a great deal of time speculatimg over how and why msider trading impairs the inarket's allocational efficiency, but there is very little evidence to support the conclusion that it does. Clearly it is a non sequitur to reason, as some commentators have, ${ }^{35}$ that the market's operation is impeded because the market would learn about the information sooner if the insider did not trade. This reasoning overlooks the fact that there is no natural connection between the insider's trading and the delay of a corporate disclosure. ${ }^{36}$ Certamly managers who have a direct and immediate gain awaiting their disclosure of corpo-

32. See, e.g., Elkind v. Liggett \& Myers, Inc., 635 F.2d 156, 172 (2d Cir. 1980); Fridrich v. Bradford, 542 F.2d 307, 321 (6th Cir. 1976), cert. denied, 429 U.S. 1053 (1977).

33. Some have suggested that the insider's trading does harm the outside investor by either preempting a price otherwise available to him or by inducing him to sell or purchase because of the increased activity in the stock. See Wang, supra note 5, at 1235 . Neither harm is likely if the insider's trading is insignificant. Even if the insider's trading is significant, the harm in the preempted price situation is likely to be small; in the increased trading situation, the insider's trading causes the parallel trader to dispose of a dog or acquire a pearl.

34. See Scholtland, Unsafe at any Price: A Reply to Manne, Insider Trading and the Stock Market, 53 VA. L. REV. 1425, 1448-49 (1967); Mendelson, The Economics Board of Insider Trading Reconsidered (Book Review), 117 U. PA. L. REv. 470, $477-78$ (1969) (reviewing H. MANNE, INSIDER TRADING AND THE STOCK MARKET (1966)); $c f$. Gilson \& Kraakman, The Mechanisms of Market Efficiency, 70 VA. L. REV. 549, 631-35 (1984) (arguing that if insider trading is legalized, insiders should be required to disclose, at some point prior to trading, the identity and size of the intended trade).

35. See Scholtland, supra note 34, at 1448-49; Mendelson, supra note 34, at 489.

36. See Dooley, Enforcement of Insider Trading Restrictions, 66 VA. L. REV. 1, 34 (1980). Nevertheless, commentators cannot obtain a complete understanding of management's disclosure 
rate information have a greater incentive to make the announcement than do managers who do not have a personal gain awaiting disclosure. On the other hand, if the imsider must sacrifice his informational advantage before he trades, then not only is his incentive to trade removed, but also his incentive to make an earlier disclosure is dampened. ${ }^{37}$

The proponents of the disclose-or-abstain rule emphasize the need to regulate insider trading because they perceive the capital market's institutional integrity as the cornerstone of allocational efficiency. ${ }^{38}$ Two questions test the accuracy of this view: How does insider trading erode the market's integrity? And how does such erosion impair allocational efficiency? The first question raises an issue that was addressed previously - whether there is a causal relationship between insider trading activity and the accuracy and timeliness of corporate disclosures. Proponents of the disclose-or-abstain rule believe that a perfectly laissez faire attitude toward insider trading would give an insider the leverage needed to manipulate the securities market to maximize his own trading agenda. Tardy corporate disclosures would be the most likely form of mampulation because the delay would give insiders and others the time needed to capture a greater share of the change in a firm's value. Ambiguous corporate disclosures and signals that are used to create market uncertainty are an even more ingenious form of nuanipulative trading practice. For example, msiders may use ambiguous announcements to enter the niarket and purchase their firm's securities at a lower price and to dispose of the stocks at a higher price following a later definitive disclosure. Insiders may even alter the timing of corporate activities for the sole purpose of creating interteniporal swings in the firm's value; they

incentives unless managenent's private trading practices are strictly regulated. See Trueman, Motivating Management to Reveal Inside Information, 38 J. FIN. 1253, 1254 (1983).

37. Professor Coffee has demonstrated that there is no inconsistency between mandatory disclosure and the prevalence of insider trading. See Coffee, Market Failure and the Economic Case for a Mandatory Disclosure System, 70 VA. L. REv. 717,740 (1984). Insiders can comply with disclosure requirements and still enjoy a trading advantage if they act before the announcennent has achieved its full effect. Moreover, the delays that oceur are likely to be minimal. See Scott, Insider Trading: Rule 10b-5, Disclosure and Corporate Privacy, 9 J. LEGal Stud. 801, 810 (1980). Finally, the disclose-or-abstain rule is likely to have little effect on managennent's tendency to delay releasing "bad news." See Givoly \& Palınon, Timeliness of Annual Earnings Announcement: Some Empirical Evidence, 57 Accr. Rev. 486, 489-90 (1982); Patell \& Wolfson, Good News, Bad News, and the Intraday Timing of Corporate Disclosures, 57 ACCT. REv. 509, 525 (1982). Some commentators hypothesize that upcoming audits, rather than the prospect of personal gain, drive management to disclose bad news. See Pastena \& Ronen, Some Hypotheses on the Pattern of Management's Informal Disclosures, 17 J. AcCT. RES. 550, 551 (1979).

38. For general descriptions of how trading in the secondary securities markets affects the allocation of resources among competing productive uses, see Fama \& Laffer, Information and Capital Markets, 44 J. Bus. 289 (1971); and Hirschleifer, The Private and Social Value of Information and the Reward to Incentive Activity, 61 AM. ECON. REv. 561 (1971). 
thereby can reap the gains of their privileged positions by anticipating the direction of the stock's price movements. These and other disclosure horrors, referred to here as abusive insider-trading practices, are the subject of a great deal of conjecture in the literature. However, there is little empirical evidence on these abusive insider-trading practices.

If extensive evidence proved that abusive practices accompany insider trading, the courts could justify the regulation of insider trading as the inost admimistrable response to curbing abusive insider-trading practices. Great uncertainty exists as to whether sound managerial judgment or the insider's hidden trading agenda drives an announcement's timing or its ambiguities, the initiation or delay of a corporate transaction, or the selection of a riskier project. Insider-trading regulation is a more administrable approach to these potential abusive insider-trading practices because it achieves two results by removing the corrupting incentive of insider-trading profits. First, regulation eliminates the highly problematic matter of proving that the manager's desire for private gain, rather than the corporate interest, motivated a disclosure, event, or project. Second, regulation focuses concern upon a single event-whether the defendant possessed and traded on confidential corporate information-which better lends itself to external analysis than does a subjective managerial business decision concerning corporate disclosures and operations. In this way, regulating insider trading eliminates the need to police a wide array of managerial misbehavior because it removes managerial incentives to engage in more serious wrongdoing.

It remains a matter of conjecture whether any, let alone a sufficient, connection exists between insider trading and the manipulation of corporate disclosures and events. Rather than leaving the question to be resolved more or less according to one's prejudices toward captains of industry, the remaining discussion in this part proceeds on the assumption that the above-described abuses would accompany the legalization of insider trading. Even with such an assumption, there is reason to doubt that the legalization of insider trading would harm the securities market's allocational efficiency.

Capital market theory offers a useful description of probable investor and manager behavior, if we assuine that investors are concerned that the deregulation of insider trading will corrupt the timeliness and authenticity of the corporation's disclosures. Insider trading occurs randomly. Inside traders generally are not repeat players because all firms do not experience the kinds of financial developments that offer extraordinary returns to insiders who trade before disclosure occurs. Moreover, regardless of the legal environment, the varying moral compunctions experienced by different managers about the propriety of their 
use of confidential information also causes randomness. On the other hand, outside investors do not know ex ante which firms' managers possess inside information; nor do they know which firms' managers will trade before disclosing that information, or will engage in abusive insider-trading practices to heighten their trading profits. Due to these informational deficiencies, the rational investor will assume ex ante that each firm poses the same risk of abusive insider-trading practices as does the market as a whole and will accordingly discount the value of each firm by the average estimated agency cost of all firms. ${ }^{39}$ Therefore, the risk of abusive insider-trading practices, even though randoin for the individual firm, becomes systematic due to the informational asymmetries that characterize public corporations. Because it is systematic, this risk cannot be reduced by diversification; an investor will merely ensure that his exposure to the harm is that of the market as a whole by adding more securities to his portfolio.

The ultimate contribution of capital market theory to the subject of insider trading is the support it gives to the emphasis on fiduciary relationships found in the Supreme Court's insider trading decisions. Capital market theory offers the compelling argument that insider trading harms the individual firm rather than the imvestor or the allocational efficiency of the securities markets. Insider trading does not harm investors because they can self-insure against abusive insider-trading practices by discounting all stocks by the average risk for all firms. ${ }^{40}$ If an investor holds an efficient portfolio, the insider trading losses on one investment will be offset by the higher return of firms whose insiders do not trade. Over time, an investor can expect that his portfoho's insider trading losses will sum to zero. ${ }^{41}$ On the other hand, the presence of abusive insider-trading

39. For a useful discussion of how buyers (i.e., investors) use various criteria to judge the quality of merchandisers, see Akerlof, The Market for "Lemons": Quality Uncertainty and the Market Mechanism, 84 Q.J. ECON. 488 (1970).

40. That such discounting occurs takes some steam out of the complaint that insider trading is unfair. The unfairness charge reflects an isolated evaluation of the insider's conduct after he has traded; if an ex ante assessment were made of the insider's right to trade which considered the investors' discounting, the unfairness charge would lose its force. See Scott, supra note 37, at 809.

41. In a related context, the author has questioned the free-market proponents' argument that it is desirable to have less demanding standards for managers, in part because owners may self-insure by holding an effieient portfolio. See Cox, Compensation, Deterrence, and the Market as Boundaries for Derivative Suit Procedures, 52 GEo. WASH. L. REv. 745, 752 (1985). Moreover, the free-market proponents must first establish not only what is wrong with the status quo, but also why investors should be driven to hold efficient portfolios. See Bebchuk, The Case for Facilitating Competing Tender Offers: A Reply and Extension, 35 STAN. L. REV. 23, 29-31 (1982). In any case, the nearly five-fold increase in the assets of mutual funds since 1980 evidences the recognition by the "little guy" that attachment to a larger investor, even for a fee, can compensate for a host of disadvantages. See Sebastian, Many Small Investors Quit Picking Stocks, Shift to Mutual Funds, Wall St. J., Feb. 7, 1986, at 1, col. 6 . 
practices increases each firm's cost of capital because investors discount all firm securities by the average risk of abusive trading practices. Therefore, inany firms will seek to lower their cost of capital in order to reduce the discount applied to them by incurring nontrivial bonding, nonitoring, and signaling costs designed both to deter their managers from abusive insider-trading practices and to signal effectively that their firm poses a lower risk of such practices. ${ }^{42}$ In considering how to reduce its cost of capital, a firm will balance the marginal cost of each additional unit of bonding, mointoring, and signaling agamst the accompanying marginal benefits of reducing its managers' trading. ${ }^{43}$ Therefore, no firm will ever be coinpletely free from investor discounting for abusive insider-trading practices because it is not economical to stop insider trading at any cost.

Some firms may discourage their inanagers from trading while others may not; the overall effect is not to eliminate this component from each firm's systematic risk, but to reduce it for all firms. Taking a market perspective, the following question arises: What are the resulting social costs if many firms' managers do not seek to distinguish themselves as nontrading managers? Some beheve this to be the case; indeed inany corporations reveal no outward concern over insider trading at least insofar as they do not establish aggressive inomitoring or bonding programs designed to discourage insider trading. 44 Because capital allocation occurs withm the context of a comparative assessinent among competing choices, any change that affects the cost of capital for all firms at the same rate will not affect the relative comparisons made by investors that

42. This multiperiod signaling model for insider trading is developed in Ross, Disclosure Regulation in Financial Markets: Implications of Modern Finance Theory and Signaling Theory, in IssuES in Financial Regulation 177 (F. Edwards ed. 1979). See also Dooley, supra note 36, at 45-47.

43. See Jensen \& Meckling, supra note 4, at 324-25.

44. Professor Mendelson was the first to argue that a firm experiencing insider trading will have a higher cost of capital. See Mendelson, supra note 34, at 477-78. If investors cannot identify which firms are experiencing insider trading, and if insider trading opportunities are randomly distributed across all frms, evidence that a particular firm is experiencing insider trading should not cause that firm's cost of capital to rise above that of other firms unless the market perceives that the particular firm has a higher-than-average likelihood of repeating the experience. If shareholders perceive that all firms have the same risk of insider trading, and firms do not signal, bond, or monitor to reduce the discount applied to them, the question arises whether an investor will favor other investment opportunities over the securities markets.

The resource question also arises when all stocks have an equal risk of abusive insider-trading practices. Assume that a firm is considering a project that offers a $9 \%$ return on investment. The lowest cost of capital for a firm of this risk classification is $9.1 \%$ in insider-trading markets. If insider-trading were regulated, the firm could offer a return of no greater than $9 \%$ to obtain the sums necessary for the investment. With insider trading legal, the firm cannot undertake the project without reducing its value, and the resources which would have been consumed in its undertaking will lie dormant or will be used in a venture of a different type. 
drive the allocation of capital among the various investment choices. ${ }^{45}$ If abusive insider-trading practices are assumed, and if firms continue not to signal their lower-than-average frequency of such practices, then the legalization of imsider trading would equally affect the cost of capital for all firms. Therefore, investors will not discriminate between firms that produce computers and those that manufacture automobiles solely on the basis of insider-trading abuses, because investors see each firm as posing the same risk of such practices. Hence, legalization of insider trading, under this "lock-step" paradigm, would not adversely affect the allocational efficiency on an interfirm basis.

The rejoinder to the "lock-step" paradigm is that even though all firms' securities reflect ex ante the same risk of insider trading, insider trading affects resource allocation because investors are not limited to securities markets. In theory, investors have many investment alterna-

45. Theorists suggest that managers who do not engage in insider trading will seek to avoid any discounting of their firms' stock by distingunshing their firms from those firms whose inanagers do trade. Monitoring, bonding, and signaling are commonly hypothesized devices to overcoine these asymmetries. Firms will undertake these acts, however, only up to the point at which their inarginal costs equal their marginal gains. Professor Dooley searched for evidence of these devices, reasoning that their existence would corroborate investors' fears concerning the effects of abusive insider trading. Professor Dooley, however, focused only on whether firms directed inonitoring, bonding, or signaling solely at their managers' trading activities. Finding no evidence of manager trading activities, Professor Dooley concluded that the case of investor inalaise is overstated and that insider trading does not interfere with the allocational efficiency of securities inarkets. See Dooley, supra note 36 , at $44-55$.

Professor Dooley's findings are consistent with two conflicting hypotheses. A failure to find evidence of signaling, bonding, or monitoring supports the hypothesis that insider trading does not harm the individual firm's securities. It also supports the hypothesis that nanagers lack a compensation schedule that aligns their utility functions with the stockholders' interests. Absent an incentive to maximize the firm's value, managers will not use such devices to distinguish their firm from other firms.

Professor Dooley may not have looked at the correct indicia of signaling, inonitoring, and contracting. He looked exclusively at arrangements that proscribed manageinent insider trading. As noted earlier, investors may not fear the insider's trading itself as much as its collateral impact on discretionary actions, such as disclosure and stewardship practices. Abundant evidence shows that corporations employ numerous devices such as independent auditors and outside directors to minimize such agency costs. See Watts \& Zinmerman, Agency Problems, Auditing, and the Theory of the Firm: Some Evidence, 26 J.L. \& EcoN. 613, 615 (1983) ("This evidence is consistent with the hypothesis that efficient, agency cost-minimizing contractual arrangements ... include monitoring and is inconsistent with the explanation that independent corporate auditing is the consequence of companies or securities acts."). Express and implied liability under the federal securities laws for misleading corporate announcements can be viewed as externally inposed bonding. Furthermore, even voluntary disclosure practices serve to signal managerial qualities and insights. See generally Cox, Insider Trading Regulation and the Production of Information: Theory and Evidence, 64 WASH. U.L.Q. 475, 492-99 (1986). These factors neither support nor undermine Professor Dooley's conclusions because it is too difficult to ascertain whether their existence stems froin the fears of investors concerning insider trading or from more sweeping concerns about managerial inisbehavior. Professor Dooley's study is focused too narrowly because a relationship between such devices and trading abuses clearly would arise were insider trading legalized. 
tives in markets where there are no informational asymmetries. For example, an investor fearing insider trading in equity securities may invest in government treasury bills, the closest available risk-free investnnent. Thus, while insider trading poses no allocational problems if investors were limited to corporate stocks and bonds, it does pose allocational problems if investors may freely withdraw from the corporate equity market and invest in different markets, instruments, or commodities. 46

This analysis, however, contains two significant qualifications which in combination erode the prevalent belief that insider trading threatens allocational efficiency. First, it is hard to envision a passive investment that is not accompanied by serious informational asymmetries. Every investment entails either a direct inanagerial component or an external component that is connected to a nuanagerial component. In either case, the managerial component provides its own opportunity for abusive insider-trading practices. For example, insider trading occurs even with the risk-free treasury bill; insiders have secretly traded in treasury bills on private knowledge concerning changes in the terms for new government offerings. ${ }^{47}$ Second, not all nivestors can lawfully acquire alternative forms of investment. The most important investors, in terms of the market's allocational efficiency, are the institutional investors that dominate current capital markets; more importantly, these institutional investors are prisoners condemned by statute or charter to continue trading in markets characterized by insider trading. ${ }^{48}$ Their sentence assures that the vast wealth they control, which today accounts for inost of the trading volume on the exchanges, cannot be inoved freely to areas where the risk of insider trading is lower. Because securities inarkets are the "only

46. Commentators believe that the potential for movement of funds across markets justifies disclosure requirements designed to reduce shareholder discounting. See Coffee, supra note 37, at 722 (mandatory disclosure system improves the allocational efficiency of the economy); Fox, Shelf Registration, Integrated Disclosure, and Underwriter Due Diligence: An Economic Analysis, 70 VA. L. REv. 1005, 1015-18 (1984) (developments in regulation of securities offerings that reduce trustworthiness of information have effect of raising cost of capital and reducing funds available for corporate expansion); Levmore, Securities and Secrets: Insider Trading and the Law of Contracts, 68 VA. L. REv. 117, $146 \mathrm{n.75}$ (1982) (discounting may cause investors to forgo purchasing securities).

47. See In re Blyth \& Co., 43 S.E.C. 1037 (1969); see also An Apparent Leak of GNP Statistics is Being Probed, Wall St. J., Sept. 23, 1985, at 18, col. 3 (reporting Treasury bond futures price rise that occurred before release of Commerce Department information that caused interest rates to decline); SEC Charges Navy Employee with Trading on Nonpublic Information About Contract, 14 Sec. Reg. \& L. Rep. (BNA) No. 16, at 682 (Apr. 23, 1982) (discussing case involving Department of Navy employee charged with purchasing stock of supplier before announcement of award of contract to supplier).

48. An excelient summary of the various portfolio restrictions imposed upon financial institutions appears in Clark, The Soundness of Financial Intermediaries, 86 YALE L.J. 1, 44 n.125 (1976). Institutional investors do spread their investments across many foreign securities markets. See Sesit, U.S. Institutions Find Buying Foreign Stocks Can Be Very Profitable, Wall St. J., June 3, 1986, at 1, col. 6. However, there is no reason to expect that insider trading does not exist in foreign markets. 
gaine in town" for a significant portion of the institutional investor's fund, the comparative assessment among competing security choices would appear unaffected. Therefore, the impact of insider trading on allocational efficiency may be overstated. Insider trading may have an effect only at the marginis and it may not impact interfirm comparisons; investors are likely to discount equally for this risk and insider-trading practices may not drive sufficient capital to other markets to adversely affect the operation of securities markets. For these reasons, if regulating insider trading serves some societal imterest, that interest must be more than an interest in inaintaining the allocational efficiency of securities markets.

\section{ARguments Against Insider Trading Regulations}

Commentators have recently advanced four arguments in support of the proposition that the present form of insider-trading regulation is unjustified and that the law should allow corporations to license their agents to engage in imsider trading. First, they argue that there is no empirical evidence that insider trading is harmful. Second, they argue that msider trading promotes stock price changes. Third, they argue that msider trading creates managerial incentives by allowing managers to unilaterally alter their own compensation packages through insider tradimg. Fimally, they argue that with deregulation, managers and stockholders would contract to license the managers to engage in insider trading because it would be to their mutual advantage to do so. Each of these positions is exannined and dismissed below.

\section{A. The "It's An Empirical Question" Argument.}

Those who abandon hope that the courts will offer insight into what harm insider trading causes frequently turn to the law and economics literature, where insider trading has been a lively topic for scholarly debate for three decades. Professor Manne's celebrated book, Insider Trading and the Stock Market, ${ }^{49}$ sharpened the issues in the debate over the purpose of insider trading regulation. Before the publication of his work, expressions such as "unfairness" and "conduct constituting a breach of fiduciary duty" used to justify insider-trading regulation. ${ }^{50}$ Unfortunately, this treatment, like the Supreme Court's reasoning in Chiarella, conceals any thoughtful explanation why the defendant's conduct should be subject to such pejorative characterizations. Manne redefined and

49. H. MANNE, Insider TRAding AND the Stock Market (1966).

50. Id. at $4-8$. 
clarified the debate by focusing on the costs and benefits of insider trading.

The perceived costs of insider trading are many. As discussed above, ${ }^{51}$ soine believe that the legalization of insider trading would corrupt the firm's disclosure practices and result in reports being delayed or otherwise manipulated to accommodate the manager's insider-trading designs. Managers who are not content to trade with the normal price changes that accompany the ebb and flow of their firm's individual performance inay aggressively embrace high risk projects in order to induce even greater swings in the stock's price. Moreover, they may time corporate activities to enhance their short-term trading goals. In addition, with a complete laissez faire attitude toward insider trading, the manager can profit as easily from bad or good news. This two-way feature is troubling. One might see the manager's holding in his firm's stock as beneficial because it more closely identifies the manager's interests with those of the outside owners; however, the gap between the manager and the outside owners widens if the manager can profit regardless of the firm's performance. In sum, if these various insider trading abuses are perceived widely enough, they will erode investor confidence in American securities markets and imcrease the cost of capital for all firms. ${ }^{52}$

The free-market proponents react to this parade of horribles by employing the well-worn debating trick of framing the areas in contention around points on which they can prevail. For example, they baldly assert that insider trading is an empirical question. ${ }^{53}$ They reason that if insider trading is harmful, there should be some empirical evidence supporting this position. On this front, their support lies in the few identifiable instances in which insider trading also led to manipulation of the corporation's disclosure or operating practices. ${ }^{54}$ The scantness of this evidence, they argue, indicates an absence of any measureable investor malaise about insider trading. ${ }^{55}$ Finding no evidence that insider trading

51. See supra note 38 and accompanying text.

52. See Brudney, supra note 3, at 356; Ross, supra note 42, at 182.

53. See Carlton \& Fischel, supra note 3, at 873; Easterbrook, Insider Trading. Secret Agents, Evidentiary Privileges, and the Production of Information, 1981 SUP. CT. REV. 309, 338; Macey, supra note 28 , at 34.

54. See Dooley, supra note 36 , at 33-36.

55. Studies show that stocks that insiders actively trade do not have larger systematic risks than stocks that insiders seldom trade. See M. MORAN, InSIDER Trading in THE STOCK MARKET: AN EMPIRICAL TEst of THE DAMage to Outsiders (Center for the Study of American Business Working Paper No. 89, 1984). There exists, of course, much anecdotal evidence to the contrary. See Insider Trading Case Reinforces Belief that Small Investor is at a Disadvantage, Wall St. J., May 20, 1986, at 2, col. 3; SEC Chief, Seeking to Reassure Investors, Says Insider Trading Cases Are Limited, Wall St. J., Nov. 17, 1981, at 16, col. 2. 
causes widespread abuses or investor malaise, the free-market proponents score the debate points.

Rephrasing the debate to focus on raw economic and empirical questions not only guides the discourse to areas where the data favors the free-market view, but it also discretely manipulates the burden of persuasion. The free-market proponents' argument that regulation is an empirical question presumes that those who favor regulation must first support their position with empirical findings. This, of course, overlooks the fact that regulation is the status quo. Because regulation is the status quo, it is more appropriate that the free-inarket proponents should carry the burden of persuasion as to whether a change is necessary. The locus of the burden is of substantial importance because the free marketers' empirical evidence is consistent with two equally plausible, yet opposite, conclusions. Studies that report neither evidence of systematic abuse accompanying imsider trading nor investor malaise over such conduct, on the one hand, support the free-market proponents' belief that insider trading is not harmful. On the other hand, these findings are equally consistent with the belief that the effects of insider-trading practices do not lend themselves to reliable empirical inquiry.

Several important factors suggest that the topic of abusive insidertrading practices does not lend itself to reliable empirical inquiry. Empiricists have difficulty in identifying the feared abuses, such as the insider trading itself. And when empiricists do isolate abuses, the connection with insider tradimg is at best speculative. So long as insider trading is criminally and civilly wrongful, ${ }^{56}$ managers will not cooperate with the empiricist seeking to reveal trading or any other abusive conduct connected with trading. Thus, enpiricists always will have difficulty establishing whether the insider's trading delayed or prompted a given activity or whether the delay or imitiation occurred naturally and merely provided the manager an opportunity to trade. ${ }^{57}$ Moreover, most types of abusive insider-trading practices involve discretionary manage-

56. See The Insider Trading Sanctions Act, 15 U.S.C. $\$ 78 u(d)(2)(A)$ (Supp. II 1984) (authorizing damages equivalent to three times the amount of insider trading profits); 15 U.S.C. $\$ 78 f f$ (Supp. II 1984) (possible criminal penalty of $\$ 100,000$ fine and five years imprisoninent); Racketeer Influenced and Corrupt Organizations Act, 8 U.S.C. $\$ 1964$ (c) (1982) (authorizing treble damages and costs, including attorney fees, in private action).

57. Abundant evidence exists that insiders systematically trade on the eve of significant corporate announceinents. See Elliott, Morse \& Richardson, The Association Between Insider Trading and Information Announcements, 15 RAND J. ECON. 521, 529 (1984) (insiders pursue active strategy of buying before release of good news as well as passive strategy of not selling before release of such news); Keown \& Pinkerton, Merger Announcements and Insider Trading Activity: An Empirical Investigation, 36 J. FIN. 855, 866 (1981) (approximately one-half of trading volune associated with inerger announcements occurs before announcement is made); Penman, Insider Trading and the Dissemination of Firms' Forecast Information, 55 J. Bus. 479, 492 (1982) (impact of forecast an- 
rial decisions for which there is an equally reasonable corporate interest that justifies a manager's decision to delay disclosure, to commence a business activity, or to report an event. Furthermore, so long as insider trading is prohibited, it will be impossible for the empiricist to observe managerial practices in a hypothesized free-market environment of no regulation. Hence, the impact of deregulating insider trading on a full array of managerial inores is beyond empirical evaluation within the current legally constrained environment. ${ }^{58}$ Finally, investor malaise over inside trading may well affect stock valuations generally, but only at the margins. That is, an investor's discounting for insider trading, if it exists, is likely to be immeasureable because it is so insubstantial. However, even undetected discounting is inconsistent with the free marketers' thesis that insider trading does not cause an adverse reaction. Moreover, even shight discounting justifies an individual firm's questioning whether it can reduce its cost of capital relative to that of the market as a whole by proscribing trading by its insiders.

These alternate explanations for the "no empirically observable" discounting emphasize the importance of which school of thought carries the burden of proof. The empirical problems inherent in the insider-trading context will always produce a factual base which supports the freemarket proponents' position, regardless of the substantive deficiencies of their views. In the end, empirical inquiry will always be unsatisfactory because the inherent secrecy imvolved with insider trading ensures that there will be no significant observable data.

\section{B. The Efficient Stock Price Change Argument.}

Without abandoning their position that the regulation of insider trading is an empirical question, the free-market proponents also argue for deregulation on nonempirical grounds. On this front, the free-market proponents employ Professor Manne's thesis that insider trading pro-

nouncement on stock prices is closely correlated with amount of insider trading occurring before announcement).

In some cases, managers have a legitimate corporate purpose for not disclosing an event. For example, in State Teachers Retirement Bd. v. Fluor Corp., 654 F.2d 843 (2d Cir. 1981), the purchaser instructed the seller to delay the announcement of a billion dollar contract for several days while financing could be arranged. During this time, insiders took liberal advantage of this external constraint on the firm's disclosure. Id. at 846-48. In other instances, the reason given for disclosure delay is much more suspect. See, e.g., Elkind v. Liggett \& Myers, Inc., 635 F.2d 156, 164 (2d Cir. 1980) (release delayed due to reluctance to correct overly optimistic financial projection). These problems justify the SEC's enforcement of the firm's disclosure duty when the firm's insiders are trading in its shares on the basis of material nonpublic corporate information. See In re Sharon Steel, [1981-1982 Transfer Binder] Fed. Sec. L. Rep. (CCH) I 83,049, at 84,618 (D.D.C. Nov. 19, 1981).

58. See supra note 56 and accompanying text. 
motes stock price changes ${ }^{59}$ and stimulates managerial performance. ${ }^{60}$ SEC v. Texas Gulf Sulphur Co. ${ }^{61}$ illustrates their first point. In Texas Gulf Sulphur, a large discovery of copper and zinc near Timmins, Ontario was not disclosed for five months so that the corporation could quietly and cheaply acquire neighboring land. Extensive insider trading occurred in the months between the discovery and its ultinate disclosure.

Using Manne's thesis, the free-market proponents erroneously counsel that the corporate interest justifies such trading because the gentle nudging of the insiders' trading activity "smooths" the movement of the stock's price to its postdisclosure equilibrium, thereby averting sharp price changes upon announcenent of the discovery. ${ }^{62}$ To the extent insider trading influences a stock's price it benefits the insider's opposite trader who on good news gets a higher price, and on bad news purchases at a lower price, than he would get had the insider not traded. On the other hand, from the perspective of the insider's opposite, this is a poor second choice to the insider first disclosing his information. The insider's opposite is far better off with the price established by the insider's disclosure of the information than he is with a price that has been inodestly nudged by the insider's secret trading. ${ }^{63}$ In the case of the insider's nondisclosure of bad news, the opposite trader emerges owning a stock that has a lower price after disclosure than its purchase price; and in the case of good news, the insider's opposite einerges having sold the security for an ainount substantially below its price following disclosure.

Certainly price changes will occur more quickly and efficiently through disclosure of the material nonpublic information than through the manager's use of personal resources and time to trade in his firm's stock. The insider's trading simply has too much "noise" associated with it to be an efficient substitute for a clarion corporate announcement. ${ }^{64}$ For example, even with the extensive insider trading activities in Texas Gulf Sulphur, there was an extraordinary price change following the dis-

59. See H. MANNE, supra note 49 , at 78-104.

60. Id. at $138-43$.

61. 401 F.2d 833 (2d Cir. 1968), cert. denied, 404 U.S. 1005 (1971).

62. See Fischel, Insider Trading and Investment Analysts: An Economic Analysis of Dirks v. SEC, 13 HOFSTRA L. REv. 127, 133 (1984) (arguing that insider trading is a valuable and flexible method for communicating information to markets).

63. Of course, if the insider refrains from trading when there is no disclosure, the investor is no better off. These effects, however, are purely redistributive, and presumably the nondisclosure advances the goals of the firm. See Levmore, supra note 46 , at 122, 132-37.

64. See Gilson \& Kraakman, supra note 34, at 631. See generally Rose, Tracking the Trades of Corporate Insiders Doesn't Always Give an Edge to Investors, Wall St. J., Dec. 19, 1985, at 31, col. 4. 
closure of the discovery. ${ }^{65}$

Cases in which there is a more modest change in the firm's fortunes are more appealing cases than Texas Gulf Sulphur for Manne's "nudging" thesis. For example, officers may early in a firm's third quarter possess nonpublic information tliat tlie firm has finally obtained control over the production costs for one of its many products while wholesale distributors are busy inquiring about two other product lines. The corporation does not disclose these facts because they are too tentative. Nevertheless, any investor selling during the period of nondisclosure would certainly benefit by whatever effects knowledge of these events will liave on the market. Moreover, the officers, who, armed with knowledge of these facts, decide that it is not time to sell tlieir firm's stock, have benefited by their use of inside information. These individuals obtain an advantage that insider-trading regulation makes available to them by proscribing only active trading conduct by the executives. Under these circumstances, an unwitting outsider may welcoine the insider's trading if it provided even modest upward propulsion in the stock's price.

This scenario appears to be the better case for Manne's nudging thesis, because the combination of the tentativeness of the information and the relatively moderate inagintude of the ultinate event-a banner quarter-coinbine to inake the imsider's trading a more acceptable signal to the market insofar as such information is less likely to be disclosed through alternative means. These factors may suggest that under such circuinstances insider trading can effect a significant portion of the price change appropriate for the information in hand. On the other hand, insiders will not gamble so much of their own momes on imformation about an event that remains inchoate. They inay purchase, but not in sufficient quantities to move the stock or to cause any eye-catching "blip" in the stock's price. More importantly, any change in the stock's price related to events such as those described above is too easily associated with the efforts of outside analysts whose persistence and resourcefulness in prob-

65. On the first day of trading after Texas Gulf Sulphur's official announcement of the Ontario strike, the stock price increased almost 24\%; it doubled within one month. Texas Gulf Sulphur, 401 F.2d at 847 .

Professor Manne's response to such evidence confuses the issue and shows a misunderstanding of the difference between pre-and postannouncement stock price changes. He reasons that the stock market efficiently reflects new information because insider trading causes the stock to change almost instantaneously. Manne, Insider Trading and the Law Professors, 23 VAND. L. REV. 547, 561 n.43 (1970). Professor Manne overlooks the fact that if insider trading did have the benefits he identifies, there would not be any significant price or volume change associated with the corporate announcement itself. Contrary to Professor Manne's assertions, price changes do follow corporate announcements and this suggests that insider trading is not an efficient signal of nonpublic information. Moreover, evidence that markets rapidly reflect new information undermines Manne's thesis. See J. CoX, Financial Information, ACCOUNTING AND THE LAW 186-87 (1980). 
ing efforts within both the industry and the firm regularly detect such changes on a daily basis. Their investigation leads ultinately to the mobilization of resources that is more hikely to account for stock changes associated with such developments. For these reasons, Manne's nudging thesis is not very compelling in even the best case scenario.

The free marketers' position that insider trading corrects the stock's price proves too much. If accepted, this position justifies massive trading and tipping to ensure that sufficient trading occurs to propel the stock to the equilibrium price appropriate for the nondisclosed information. Such widespread trading, however, compromises the corporate interest that justified nondisclosure in the first place. Therefore, all tips to outsiders must be on the basis of either ambiguous or misleading information so as to conceal the correct confidential information. Ambiguous or misleading statements, however, will not perfectly match the correct confidential information. Such surreptitious trading practices will therefore necessarily be inefficient in terms of prompting the price changes that are appropriate for the correct, albeit concealed, information. If we accept such ambiguous and misleading tipping practices as lawful devices that can be used to achieve an equilibrium market price prior to the disclosure of the correct information, it logically follows that the corporation should be able to announce a completely false event, so long as its magnitude is believed equal to that of the nondisclosed true event. This reasoning would have authorized Texas Gulf Sulphur to announce that a single core drilling in Peru revealed unusually large levels of uranium in November, 1963.

Fortunately for those of us who feel more secure with legal regimes that discourage manipulation and encourage full disclosure, we are spared this logical extension of Manne's "nudging" thesis. The savior in this case is, as we have seen, that Manne's thesis has no reliable support in either theory ${ }^{66}$ or einpirical data. ${ }^{67}$

66. The deficiencies of insider trading as either a signal or other mechanism to drive prices to the equilibrium appropriate for nondisclosed material information are described in Gilson \& Kraakman, supra note 34 , at 572-79. These deficiencies are exacerbated when the insider conceals his identity or otherwise hides his trading activities.

67. Empiricists have studied a variety of corporate announcements to determine the relation. ship between the amount of insider trading occurring prior to an announcement and the impact of the announcement on the stock's price. The evidence shows that systematic insider trading occurs prior to the announcement and that a significant change in the stock's price occurs with the actual announcement. This suggests that insider trading is not a completely efficient communieator of information. 


\section{The Incentive Compensation Argument.}

Because the choice between disclosure and abstention entails two rather unburdensome options, one may wonder why the free-market proponents argue in favor of trading and nondisclosure, especially when disclosure is the most effective way to drive the security to its intrinsic value. The argument that insider trading is socially beneficial because it nudges a security's price to its appropriate equilibrium is so disingenuous that it suggests that the free marketers do not make it in good faith, but only use it as a transparent justification for solne larger agenda. Their embrace of imsider trading fulfills the free marketers' prescription for what "ails the American corporation"-managerial lethargy and risk aversion. ${ }^{68}$ For these crippling afflictions, free marketers prescribe various managerial "self help" coinpensation arrangements, ${ }^{69}$ one of which is insider trading.

To free-market proponents, managerial incentives are found first in coinpensation arrangements and second in competitive markets for managers and control. Compensation arrangements are intricate and must be reviewed and renegotiated periodically. Such negotiations, however, are time consuming and can involve the expenditure of nontrivial resources, especially for the large public corporation. The free-market proponents see insider trading as a ineans to avoid such periodic and wasteful negotiations, and propose that managers be hicensed to alter unilaterally their own coinpensation packages through insider trading..$^{70}$ Like those who see children as always being responsible enough to decide how much of a sweet to consume before meals, the free-market proponents see managers as being responsible enough to accede only to the right amount of insider-trading profits. They further beheve that managers who are free to trade will be stimulated to generate new information in order to provide themselves with further opportunities to gain by trading prior to disclosing the value-increasing event. The owners also benefit because such value-enhancing information means new developments, new markets, and other corporate events that increase the value of the firm.

The free-market proponents envision the manager's compensation package as having upside potential, even in a down market. They argue that managers should be free to gain from events that decrease as well as

68. See H. MANNE, supra note 49, at 578-79; Cariton \& Fischel, supra note 3, at $861-66,881$; Macey, supra note 28 , at $30-32$.

69. Some would expand the manager's rewards beyond mere inside trading to include appropriating the corporation's business advantages and ultimately the owners' continuing interest in the firm. See Easterbrook \& Fischel, Corporate Control Transactions, 91 YALE L.J. 698, 705-06 (1982).

70. See H. MANNE, supra note 49, at 138-41; Carlton \& Fischel, supra note 3, at 870-71; Macey, supra note 28 , at $39,46,57-58,62-63$. 
increase the value of the firm. Permitting managers to profit on bad news, they argue, is necessary to overcome the manager's aversion to risk: ${ }^{71}$ the manager will be more willing to embrace risky ventures if he is aware that a venture's failure can nevertheless be turned into his gain by sellimg short before announcing the failure. Licensing managers to trade on inside information provides a means to reward the manager who tried and failed. Insider trading, therefore, becomes a device for rewarding socially beneficial entrepreneurial risk-taking.

With such a perception of the potential benefits of insider trading, the proponents of the free-market view conclude that if managers and shareholders could costlessly contract, they would see that licensing managers to trade on inside information is in their inutual interest. ${ }^{72}$ In this respect, the private contracting approach to insider trading is a natural adjunct to the free marketers' familiar refrain that the corporation is but a nexus of important contractual relations, ${ }^{73}$ the most central being the one between owners and their managers. In this realm, managers and owners trade off costs and benefits. Therefore, stockholders will allow the msider to be compensated in a manner that will most likely stimulate entrepreneurial activity so that they can receive the benefits of heightened managerial effort and talent. These tradeoffs should nevertheless be judged by their relative costs and benefits. As explained below, the free-inarket proponents give insufficient attention to the costs of insider trading when weighing the assumed benefits.

First, the free-market proponents overlook the alternative dispositions that the firm could inake with its inside information. For example, in a completely laissez faire environment, the firm could consider selling the information to one or more traders who could thereby reap the spread between what was paid to the firm to acquire the information and the gain derived by trading on the information's nondisclosure. Such marketing of the inside information has a leveraging effect of enhancing the wealth of remaining stockholders by appropriating more of the gain through the firm rather than the market. The firm's potential gains from such dispositions are considerable and could easily swamp those that the free-market proponents assert would accrue by licensing the firm's insid-

71. See Carlton \& Fischel, supra note 3, at 873-76.

72. See, e.g., Cariton \& Fischel, supra note 3, at 871 (insider trading increases the manager's incentive to acquire and develop valuable information); H. MANNE, supra note 49, at 132-33 (arguing that if large corporations are to survive, a form of compensation must be devised that rewards individual entrepreneurial effort).

73. The seminal explication of this theory is found in Coase, The Problem of Social Cost, 3 J.L. \& ECoN. 1 (1960). Professor Coase rejects the argument that free marketers draw from his work because he assumes that parties possess perfect information before contracting. As discussed below, this is not possible with respect to insider trading. 
ers to trade. To be sure, information is a public good in that selling it to one person does not prevent another's use of that information. But in the context of using corporate confidential information in capital inarkets there is a crowding-out effect, whereby one person's use can easily lead to another's indirect trading so that a later trader does not reap as great a market advantage from the same information. Therefore, a firm wishing to consider alternative dispositions of inside information could rightly see that such uses must foreclose trading by its managers. In any case, the free-inarket proponents should consider the benefits of the firm's alternative uses and dispositions of inside information in evaluating the dedication of inside information as a managerial prerequisite.

Second, the free-market proponents' belief that insider trading is necessary to increase entrepreneurial activity is vulnerable on many points. In several other areas of managerial beliavior, the free-market proponents have counseled deregulation based on their unqualified belief that the competitive markets for managers and control pose a means to displace managers who are risk averse, inefficient, or who otlierwise fail to maximize share values. In those areas, they believe the market offers sufficient stimuli for the managers to excel. ${ }^{74}$ The free-market proponents, lowever, do not consider market-based forces wlien they promote insider trading as a necessary incentive for valuable entrepreneurial activity. As discussed above, ${ }^{75}$ the free-market proponents prescribe insider trading as a device to overcome the manager's aversion to risk. However, inanagers who may profit equally from the corporation's gains as from its losses can be seen as neutral to wlrichever event occurs. Witlin sucl a compensation arrangement, the manager's incentives are hopelessly confused and certainly are not focused exclusively upon the stocklolders' interest in maximizing the firm's value. Therefore, rather than

74. The free-market proponents generally favor deregulation in several areas of managerial behavior because competitive markets for managerial talent and corporate control efficiently displace managers who fail to maximize share values. In those areas, they believe that market forces will stimulate managers to excel. See Easterbrook \& Fischel, The Proper Role of a Target's Management in Responding to a Tender Offer, 94 HARv. L. REv. 1161, 1173 (1981); Fischel, The Corporate Governance Movement, 35 VAND. L. REV. 1259, 1288 (1982); Fischel, The Efficient Capital Market Theory, the Market for Control, and the Regulation of Cash Tender Offers, 57 TEx. L. REv. 1, 7-8 (1978); Fischel \& Bradley, The Role of Liability Rules and the Derivative Suit in Corporate Law: A Theoretical and Empirical Analysis, 71 CORNELL L. REV. 261, 275-76 (1985); Manne, Mergers and the Market for Corporate Control, 73 J. PoL. EcoN. 110, 118 (1965). To be sure, the corporate control and managerial talent markets are not perfect. The nature of team effort makes the managerial talent market a forgiving one, and it requires grand scale ineptitude to motivate a firm to displace another firm's incumbent management in order to acquire control. Commentators also believe that the derivative suit will provide an incentive for those managers whose inefficiencies and misbehavior have not reached the displacement level. See, e.g., Anderson, Conficts of Interest: Efficiency, Fairness and Corporate Structure, 25 UCLA L. REV. 738, 790-91 (1978).

75. See supra notes $70-71$ and accompanying text. 
driving managers to be risk preferring, the free-market proponents' solution enables managers to hedge on any decision and thereby become gain-neutral.

Third, the free-market proponents assert that an additional benefit of imsider trading is that the compensation it produces is essentially selfestablished because it is contingent upon events largely within the inanagers' control. This argument's complete lack of novelty alone challenges its wisdom. Large public corporations today base a substantial percentage of managerial compensation upon bonus arrangeinents conditioned on some identifiable level of firm performance. ${ }^{76}$ While the criteria by whicl the bonus level is identified are objective, a fainiliar criticism of executive bonus arrangements is that such criteria are witlin the control of the executives. ${ }^{77}$ Because arrangements sucl as these already confer large financial rewards upon inanagers, it is extremely doubtful that those in the managerial ranks feel that they are seriously undercompen-

76. Earlier studies indicate that a significant portion of an executive's contingent compensation was tied to changes in the firm's stock value. See Easterbrook, Managers' Discretion and Investors' Welfare: Theories and Evidence, 9 DEL. J. CORP. L. 540, 559-61 (1984); Vagts, Challenges to Executive Compensation: For the Markets or the Courts?, 8 J. CoRP. L. 231, 247-52 (1983). Management compensation practices changed when the bear market in the latter half of the 1970's placed a drag on management compensation. An ever increasing portion of the executive's total compensation package, the bonus, is tied to contingent events that are not based on the firm's stock value. One report placed the average bonus for chief executives at about $70 \%$ of annual salary. See Johnson, Big Executive Bonuses Now Come With a Catch: Lots of Criticism, Wall St. J., May 15, 1985, at 33, col. 4.

Professor Manne has a low opinion of these contemporary bonus plans. He does not base his opinion, however, on a close analysis of the way the plans operate. He believes a major deficiency in contingent bonus plans is that the people evaluating a manager's compensation level may not appraise the manager's talent as highly as the manager himself values it. See H. MANNE, supra note 49 , at 141-43. Thus, rather than being free to set his own compensation through insider trading, the manager may have to dicker over his worth.

Professor Manne's criticism of contemporary contingent bonus plans contradicts the current free-market position that legal rules reflect the bargain that the parties would enter into if they could costlessly contract. Professor Manne's view ignores the fact that both parties to an exeeutive compensation arrangement have found the terms of that arrangement to be appropriate.

77. To the extent that these bonuses depend on financial figures rather than market values, they are subject to manipulation within reasonable ranges. See generally J. Cox, supra note 65, at 453-59 (dealing with overall corporate smoothing of reported income); Brindisi, Why Executive Compensation Programs Go Wrong, Wall St. J., June 14, 1982, at 20, col. 3 (executive compensation packages do not benefit shareholders equally). The ability to manipulate the bonus increases when performance is based on short time horizons. See Rappaport, Don't Sell Stock Market Horizons Short, Wall St. J., June 27, 1983, at 28, col. 3. Nevertheless, executive bonus arrangements more recently have begun to reflect a reward for gains directly connected to the executive's contributions. Moreover, these arrangements tie the rewards to gains within the firm over a three- to five-year period. See Bennett, More Managers Find Salary, Bonus Are Tied Directly to Performance, Wall St. J., Feb. 28, 1986, at 27, col. 5. 
sated 78 and are clamoring for insider-trading profits as an incentive reward for further efforts. In this regard, it is significant that most insidertrading cases have not involved those whose entrepreneurial or other managerial efforts have produced the value-increasing event that was traded upon. Instead, the defendants have been outside directors, professionals, or clerks whose assistance was used to complete the transaction, not to create it.

In combination, these three coinplaimts strike at the free-market proponents' thesis that inside trading will stimulate socially useful managerial and entrepreneurial activity. On reflection, the prevailing systein of market-based penalties and performance-based reward mechanisms provides substantial incentives without the problem of gam-neutral managers or abusive insider-trading practices. ${ }^{79}$ The argument that corporations should be allowed contractually to license their executives to trade on inside information contains an even more fundamental flaw: parties can not efficiently contract without reliable cost/benefit information. This flaw is closely examined in the following section.

\section{The Licensing Through Contracting Argument.}

The doininant constraint to the belief that parties will enter into mutually advantageous contractual arrangements is that they nust know the consequences of their acts. It is essential, therefore, that parties know the costs and benefits of their actions if they are to negotiate a mutually advantageous contract. ${ }^{80}$ Estimating costs and benefits is practical in a good many legal areas. For example, certain torts such as nuisances lend themselves to privately negotiated settlements because the

78. One survey shows that the average chief executive of a public corporation earns over $\$ 750,000$ per year, and that the average outside director earns over $\$ 279,100$ per year. HEIDRICK \& Struggles, Director Data 8 (1982).

79. Judge Easterbrook reports that managers of large corporations own an average of $\$ 150,000$ of their firm's stock and that share values increase upon adoption of long-term compensation plans that increase management's ownership interest. Easterbrook, supra note 76, at 540, 558 (1984). This evidence supports the view that corporations can develop compensation plans without hidden costs which benefit stockholders.

80. In most contracting situations the parties do not know their respective costs and benefits because of numerous unpredictable variables over which they have no control. Nevertheless, estimates of the range of the possible outcomes are a necessary part of rational contracting. Such estimates do not reduce the parties' uncertainty over the ultimate benefits to be derived from their contract. However, numerous standard form terms in contracting owe their existence to the contribution they make toward reducing the parties' uncertainty over the expected costs and benefits. See Goetz \& Scott, Principles of Relational Contracts, 67 VA. L. REV. 1089, 1095-1 10 (1981). In the case of contractual arrangements involving personal services, general fiduciary obligations are a substitute for the standard contracting form that may otherwise be used to reduce the parties' uncertainty over the level of performance. Id. at 1126-30. Even here, there is a balance of each party's respective costs and benefits. Id. at 1129 . 
parties can compare the plaintiff's nuisance damages to the defendant's abatement costs as well as the defendant's benefit from engaging in the nuisance activity. ${ }^{81}$

Unfortunately, it is not as easy to estimate the costs and benefits of insider trading, for the problem of quantification is substantial. In the case of insider trading, stockholders inust not only be able to quantify the benefits-such as increased efficiency and more aggressive entrepreneurial activity-that they will receive froin licensing managers to trade on confidential corporate information, but they also must know whether and by what amount these benefits will be accompanied by costs such as abusive insider-trading practices. Because so much of the activities of a business are teain functions and frequently the result of forces beyond management's control, it is difficult to quantify the gains attributable to entrepreneurial activity generally, let alone the gains attributable to each individual manager's contribution toward these benefits.

Moreover, the costs of insider trading are open-ended. Minimally, insider-trading costs amount to a transfer of wealth to the inside trader from his opposite trader. In the case of good news, the insider can purchase shares in the inarket to the extent that his personal resources permit. A manager's gain, however, is not hinited to the annount of personal wealth that he commits to trading. Options trading greatly expands the insider's trading gains and, hence, wealth transfers to the insider. ${ }^{82}$ In the case of bad news, the accoinpanying welfare transfer is also immeasureable because the insider can engage in short trading..$^{83}$ In sum, the opposite trader's insider-trading costs are beyond quantification. Furthermore, hidden costs associated with various abusive insidertrading practices inust also be taken into account. As discussed above, the existence and magnitude of such costs pose an insolvable problem, especially in the context of ex ante contracting.

To be sure, the parties inay establish an arbitrary ceiling on the insider's gains; this approach, however, does not ensure that owners will beheve it is in their interest to contract. ${ }^{84}$ Even though the parties can

81. See generally R. POSNER, ECONOMIC ANALYSIS OF LAW 122-24 (2d ed. 1977).

82. In one instance, an AMAX director's son earned $\$ 427,000$ in just 48 hours by purchasing an option for \$3,125 on a tip from his father that AMAX would soon announce a merger with Standard Oil of California. See Longstreth, SEC Battle against Insider Trading Is Worth the Effort, Legal Times, May 10, 1982, at 16, col. 2.

83. Section 16 of the Securities Exchange Act, 15 U.S.C. $\$ 78 p$ (c) (1982), currently prohibits officers and directors from selling shares short. See Carlton \& Fischel, supra note 3, at 893-94.

84. Both Professor Brudney and Professor Clark make the important point that the contract analogy is flawed because officers technically are not the agents or employees of the shareholders. Officers are appointed by directors who oversee the corporation's affairs. See Clark, Agency Costs Versus Fiduciary Duties, in PrIncipals AND Agents: THE Structure of Business $55-58$ (1985); Brudney, Corporate Governance, Agency Costs, and the Rhetoric of Contract, 85 CoLum. L. REv. 
artificially establish a ceiling on the insider's trading profits, so that at least one dimension of the cost to owners is contained, there remains great uncertainty over whether the owners can reasonably expect benefits of an annount sufficient to justify these costs. Such a ceiling would likely have to reflect each insider's umique characteristics, including his personal indifference curve. This individual tailoring robs insider trading of its purported virtue of being a coinpensation mechanism that avoids costly contracting and inonitoring. Moreover, a ceiling on insider trading would not contain the other costs associated with abusive insidertrading practices. The hicense to trade, even if trading is reasonably limited, can still provide ample incentives for costly inamipulative practices. Finally, any ceiling arrangeinent is fraught with the substantial incentive for the manager to secretly trade so as to reap gains greater than those permitted by the contract's terms. ${ }^{85}$

The contract analogy simply fails to offer a workable forinat because its central condition - a capability on the part of the parties to reliably estinate their respective costs and benefits-calmot be satisfied in the case of insider trading. This does not mean, however, that the reference to contracting is futile or without significance. Quite to the contrary, the parties' hikely contracting positions reveal that owners would not beheve that it is in their best interest to license managers to trade.

\section{The CORPoration's INTEREST IN REgulation}

Those who champion the view that stockholders will benefit by privately contracting for all matters of managerial discretion overlook the inherent institutional probleins of the public corporation that impair the parties' incentives and ability to contract optimally. The separation of ownership from management problem is easier to overcome through contracting when there is a single owner than when there are large numbers of passive owners. The single owner will seek to reduce managerial shirking, self-dealing, and cheating so long as the costs of his efforts do

1403, 1428-30 (1985). This distinction, while an important one, does not completely dispose of the question. Shareholders do elect their directors, and, therefore, any concern over the officers' stewardship can impact the shareholders' decisions in nominating, voting for, or removing directors.

85. There is every reason to believe that managers will not find insider trading to be desirable if it results in an equal reduction in their fixed compensation. Risk averse managers will prefer a fixed salary of $\$ 100,000$ over a fixed salary of $\$ 50,000$ plus a $10 \%$ chance of $\$ 500,000$ insider trading profits. The amount of potential insider trading profits needed to make the two types of compensation arrangements equivalent will differ in accordance with individual indifference curves. This makes it difficult to impose ex ante any meaningful ceilings on their trading profits because of the necessity to tailor each ceiling for the individual manager. 
not exceed the expected benefits. ${ }^{86}$ The contracting costs are greater for the public corporation because there are a greater number of units within the bargaining group. In addition, eacli stockholder receives only a proportionate share of the expected benefits. Both the presence of high costs and sliared benefits discourage stockholders from privately contracting with their managers. ${ }^{87}$ Stockholders will not expend their own resources to constrain managerial misbeliavior because the passive stockholders will still receive a proportionate share of the resulting benefits; this free rider problem discourages any stockholder from taking action. ${ }^{88}$ Alternatively, poor coordination among stockholders may result in a duplication of efforts, leading to excessive monitoring and contracting. ${ }^{89}$

For these reasons, the developed standardized rules, which may take the form of statutory directives or common law obligations, approximate the bargain that stockholders and managers would strike if they could contract at no cost. Free-market proponents view such externally developed rules as socially optimial substitutes for uneconomical private contractimg. 90 Others might see this as too narrow a view of the role and content of fiduciary obligations. A middle ground between these two views is to reason that an arrangeinent which stockholders would never enter into if they could costlessly contract should not comprise an externally imposed fiduciary obligation. It is this point that is used below in rejecting the free-market proponents' belief that insider trading should be deregulated.

86. This is not to suggest that one or more owners do not need standardized obligations. It is not economical or practicable to specify all the details necessary to regulate the manager's behavior. Nor is it desirable that provisions common to such arrangements must constantly, like the wheel, be reinvented and renegotiated. Hence, the desirability of enactments such as the Uniform Partnership Act and of the development of generalized fiduciary obligations of agents has been recognized. Sce W. KLEIN, Business ORganization AND FiNANCE 61-69 (1980).

87. See Anderson, supra note 74 , at 778-81.

88. Id. at 778-80.

89. High communication costs for a large group of stockholders can cause coordination problems. These problems are exacerbated if time is of the essence. Thus, rational stockholders will enact measures to reduce their coordination costs and eliminate time pressures. One classic illustration is the imposition of a supermajority voting requirement before the firm can be acquired. See Carney, Shareholder Coordination Costs, Shark Repellants, and Takeout Mergers: The Case Against Fiduciary Duties, 1983 AM. B. FouND. REs. J. 341, 374-78. Another illustration is the imposition of cumulative voting, see Anderson, supra note 74, at 779-80.

90. This is not to suggest that the characteristics of fiduciary standards will be identical to the characteristics of private contracting standards. See Clark, supra note 84, at 71-76 (faulting economists for overlooking important differences between the four identifying characteristics of fiduciary duties). Collectively, a large group of shareholders bargain for results that differ from those bargained for by a small number of individuals. Inquiry into stockholders' interests is, as Clark's own reasoning reveals, id. at 77-78, a useful beginning point. It seems more appropriate to say that externally developed rules at a minimum reflect what the parties would have provided for if they could have costlessly contracted. 
A further consideration of the nature of externally imposed fiduciary obligations in the form of insider-trading rules is their collateral benefit of overcoming the natural bargaining advantage managers enjoy over remote owners. ${ }^{91}$ If only private contracting existed, the manager's advantage would enable him to manipulate the terms of the agreement to his own benefit. This feature is particularly important in the area of insider trading. Management unquestionably has an incentive to acquire shareholders' stock at discounted prices by insider trading or leveraged buyouts. It is therefore in the manager's interest to manipulate the contract to earn the rewards of apparently complying with its provisions and at the same time secretly trading outside his estabhished compensation schedule. For example, it is not surprising to find that while bonus arrangements recently have become the dominant part of managerial compensation packages, they generally are not measured by criteria which tie managers' gains to increases in shareholder wealth. For these reasons, private contracting arguments are better understood as suggestimg that the foundations of externally imposed rules are minimally those requirements which the parties wonld have agreed to if they conld have costlessly contracted.

As discussed above, there is no basis to behieve that authorizing managers to engage in insider trading is in the shareholders' interest. Managers control the knowledge of such an arrangement and therefore have an incentive to overstate not only the total amount of the benefits, but also their contribution toward those benefits. Also, there is no reliable means by which the shareholders can satisfy themselves that an appropriate balance is nianitained between those benefits and the attendant insider-trading costs. An external prohibition of imsider trading can therefore be justified on the basis that stockholders have hittle to gain and much to lose by licensing their managers to trade on mside information. In this way the prevailing prohibition is consistent with what the parties would have privately agreed to were such negotiations practicable. That is, in place of a compensation device so ripe with informational asymmetries as insider trading, shareholders will rationally prefer unqualified openness for their managers' compensation arrangement. The prohibi-

91. See Anderson, supra note 74, at 781 (noting that managers have no interest in drafting contracts adverse to their own interest); Easterbrook \& Fischel, supra note 69, at 702 (noting that managers will manipulate articles to their own advantage). Small investors tend to support charter provisions designed to discourage the takeover of the firm because they are not likely to have the incentive to scrutinize managements' true motives; institutional investors, on the other hand, usually disfavor such provisions. This indicates that managers may be taking undue advantage of the small stockholders. See Gilson, The Case Against Shark Repellent Amendments: Structural Limitations on the Enabling Concept, 34 STAN. L. REV. 775, 822-27 (1982). 
tion of insider trading achieves this result. ${ }^{92}$

At least three reasons other than the uncertain costs and benefits of a free-market approach to insider trading also justify the insider trading prohibition. First, knowledge of an executive's compensation sources is indispensable for understanding what motivates his discretionary behavior. When an executive's compensation is tied to changes in the firm's value, or his renewal is conditioned upon achieving a stated performance level, investors are better assured that the manager will act in the shareholders' best interests than when compensation is not linked to an interest held by the shareholders. This knowledge also permits superiors to rely upon the same assumptions regarding their subordinates' activities. Investors and superiors can form these assumptions more easily when the compensation arrangement is free from the noise that insider trading creates by allowing managers to wm with both good and bad news.

Second, an assessment of the manager's stewardship of the firm (an assessment dear to the hearts of free-market proponents as well as those who are not entirely comfortable with a free market) can occur only with full knowledge of both the executive's costs and his team's productivity. ${ }^{93}$ Licensing managers to trade on inside mformation is similar to hicensing managers to embezzle because in both cases the individual investor cannot assess the firm's return on its capital or the manager's compensation in light of his productivity. Therefore, shareholders expect a

92. My position that insider trading regulation is justifiable implies a rejection of the prevalent notion that investors have a private right of action for the manager's violation of the disclose-orabstain rule. Recognition of a private right of action is of no consequence, though, because the private litigant has been a free rider to the detection and enforcement efforts of the SEC in insider trading cases. See Dooley, supra note 36, at 8-18.

Professor Macey has concluded that all insider trading regulation should be privatized. See Macey, Too Strict a Crackdown Will Harm Markets, Wall St. J., May 28, 1986, at 34, col. 4. This conclusion is not well-founded. The elaborate market surveillance devices that exist within various organizations as well as the increasing sophistication of order processing suggest that there are economies of scale in the enforcement of insider-trading rules. Just as one would certainly not deprive the comer gas station of local police protection, it is unreasonable to suggest that there is no role for public enforcement because employers will terminate their inside traders who are discovered. Moreover, the presence of distinct social and psychological barriers within the American corporation makes it doubtful that the corporation can clean its own stable. See Cox \& Munsinger, Bias in the Boardroom: Psychological Foundations and Legal Implications of Corporate Cohesion, 48 LAW \& CONTEMP. ProBs., Summer 1985, at 83, 83-108.

93. Some important insiders are not full-time employees, but outside directors and various professionals retained by the corporation for specialized projects. This group, however, has the weakest claim to any insider-trading prerogatives. Not among the "movers and shakers" championed by the free-market proponents, they are either highly compensated footmen (in the case of lawyers and accountants) or highly reliable monitors (in the case of directors) employed to curb management's misperception of the corporate interest. In either case, because an outsider's functions and compensation customarily are well understood, it is unfair for the outsider to secretly augment that compen. sation without prior consent. 
regime that prohibits employment-derived earnings that are neither authorized nor fully disclosed. This is accoinphished by prohibiting insider trading.

Third, shareholders expect the executive to concentrate on their welfare rather than his private investment agenda. The prohibition agamst insider tradmg is similar to the prohibition against a manager spending his time in the office developing his own interests; each prohibition stems from the shareholders' expectation that a manager is paid to look after the shareholders' welfare, not hïs own.

These three aspects of the employment relationship justify the continuation of insider trading regulation because employers, like consumers, have rationally based expectations about what they are purchasing when they hire managers or other professionals. Without a prior understanding between the firm and its insiders regarding the latter's trading prerogatives, the parties expect that the insider's compensation will be no more and no less than what their agreement provides. An insider unlawfully acquires gains by embezzling firm assets, deflecting a corporate opportunity, or using corporate infornation, because these matters are outside the employment contract. The parties could have raised these inatters in their negotiations. Because owners, acting rationally, would see that licensmg an insider to trade leaves nothing to be gained and a good deal to be lost, they will not license their insiders to trade. Therefore, the insider breaches his eniploynient agreement when he trades.

The earher discussed arguments of the free-market proponentsconcerning einpirical evidence, efficient price changes, and managerial incentives-independently fail to justify a laissez faire approach to insider trading. And, im light of the potential costs and questionable benefits of licensing managers to trade, the free-market proponents' notion of private contracting fails to justify deregulation. The irony for the freemarket proponents' position concerning the desirability of private contracting is that the prohibition against insider trading is justified, not in spite of contract principles, but because of then. 